\title{
WestVirginiaUniversity
}

THE RESEARCH REPOSITORY @ WVU

Volume 29 | Issue 2

Article 5

January 1923

\section{Some Current Activities of the American Bar Association}

John W. Davis

American Bar Association

Follow this and additional works at: https://researchrepository.wvu.edu/wvlr

Part of the Legal Profession Commons

\section{Recommended Citation}

John W. Davis, Some Current Activities of the American Bar Association, 29 W. Va. L. Rev. (1923).

Available at: https://researchrepository.wvu.edu/wvlr/vol29/iss2/5

This Article is brought to you for free and open access by the WVU College of Law at The Research Repository @ WVU. It has been accepted for inclusion in West Virginia Law Review by an authorized editor of The Research Repository @ WVU. For more information, please contact ian.harmon@mail.wvu.edu. 


\title{
SOME CURRENT ACTIVITIES OF THE AMERICAN:
}

\section{BAR ASSOCTATION.*}

\author{
Bx John W. Davis.**
}

Some ten months ago, with the lighthearted irresponsibility that: prompts the signing of all long time notes, $I$ accepted an invitation to attend this meeting of the West Virginia Bar and oceupy a: place on its program. At that time the prospect was alluring. It appealed, in the first place, to the sense of homesickness never entirely absent from a wanderer's breast. When for twelve years one's contact with his native soil has suffered a succession of rude interruptions, he becomes eager to reestablish himself in the fellowship to which he was born. I knew, moreover, from personal. observation that the West Virginia Bar Association as an audience, is not only capable of great endurance, but that it is slow to anger, plenteous in mercy and can be relied upon to show charity to a returning prodigal; but I confess I never dreamed that ten months could roll around in so short a time or that when pay-day came, President Brown would prove so inexorable a collector.

When I was drafted by the American Bar Association for a year of enforced labor-which I can assure you proves not to be trifling -I fancied that $I$ was automatically released from this and all like engagements because of a material change in the conditions con. templated by the contract and a resulting impossibility of perform. ance. The only response to this suggestion was a threat of excom. munication by book, bell and candle, and summary expulsion from the ranks of this association. To avoid these drastic and Dracon. ian penalties, I am here.

Members, however, have rights, not less sacred because they chance to differ from those of imported guests and orators. It is one thing, as we have all learned, to compel the attendance of a witness, quite another to put words into his mouth, and still an. other to get them out again after they have been put there. It is one thing to command a speech, but far more difficult to control

\footnotetext{
- Address delivered before the West Virginia Bar Association at Euntington, Norem. ber 16, 1922.

- President of the Amerlcan Bar Association.
} 
the theme; and so, instead of endeavoring to stir this gathering with high discourse and with flowers plucked from the fields of rhetoric, $I$ am going to exercise such liberty of choice as remains to me and improve the occasion by talking shop concerning the American Bar Association and some of its current activities.

In common with most organizations formed to advance the seience of jurisprudence, promote the administration of justice and uniformity of legislation and judicial decision throughout the nation, to uphold the honor of the profession of the law and encourage cordial intercourse among the members of the bar, the American Bar Association deals and has dealt with a wide variety of subjects. It can look back over its forty-six years of life with no small sense of accomplishment. Its constant increase in membership clearly points to greater tasks and wider influence in the future. Those who were in attendance at the San Francisco meeting realize, if they survived the hospitality of our Pacific brethren, that the encouragement of cordial intercourse was not forgotten on that occasion. A glance at the minutes of the meeting and the reports submitted to the general body and its various sections reveals moreover a truly remarkable range of subjects considered and discussed-Professional Ethies, Uniform Laws, Commereial Arbitration, The Permanent Court of International Justice, Declaratory Judgments, Suits in Admiralty against the United States, Uniform Judicial Procedure, Legal Aid, Aeronautics, Internal Revenue and Trademarks-these were but some of the matters claiming the time of the Association. Of these, some were old friends whose recurrence proves that progress can come only by keeping eternally at it; others were new and had just started on the road, long or short, that leads to accomplishment.

One thing, however, which made the meeting unique was the rather conspicuous absence from the field of discussion of the subject of Legal Education, over which so many battles have been waged. This absence was due, I am sure, not to any falling off in interest, but to the fact that as a result of action taken at Cincinnati in the heated term of 1921, and later at the conference of the Bar Association Delegates at Washington, the attitude of the American Bar Association on the subject had been defined and the debate transferred to other fields. Undoubtedly, the Washington conference of February, 1922, was the largest and most representative gathering ever assembled for the single purpose of setting things right in the field of legal education. Forty-four state bar zssociations were represented, one hundred sixteen local or foreign 
bar associations ands twenty seven law schools. That it adopted by an overwhelming majority, albeit not without dissent, the standards proposed by the Council on Legal Education of the American Bar Association, means that the movement has passed beyond the sphere of academic discussion and has enlisted organized support.

Since the Washington conference was held in February, its action has been endorsed without qualification by the Bar Associations of Oregon, Michigan, California and Minnesota. The Associations of Ohio, Wisconsin and Louisiana have discussed the matter without taking final action. The Nevada Association, while in general agreement with the standards proposed, found itself confronted by the peculiar situation of having no law school within the borders of the State, and therefore was constrained to content itself with approving the requirement of two years' study. in college, to be followed by three years' study of law, the latter, however, not of necessity in a law school. In Tennessee the Bar was not prepared to approve the immediate adoption of the Washington standards, but did recommend a substantial advance in the requirements for admission. So far as I am aware, this is the sum total of action taken by the organized Bar since the Washington Conference adjourned. But Kansas, with the boldness which has put her in the front of so many movements, has announced through her Supreme Court that, beginning with the examination of June, 1924, the equivalent of one year's study in a general college course, and with that of June, 1926, the equivalent of two years' study in a general college course will be required of all applicants for admission to the Bar.

Most of us here have lived to see substantial changes in the standards for admission to the Bar in West Virginia. Fortunately, perhaps the requirements in the old days were not exacting; the alleged examination before three judges-seriatim-was not usually of a searching character. In one instance, at least, I have reason to know that the candidate was admitted after being asked whether he knew about the rule in Shelley's case, and his response that he thought he did. Thanks in the main to the labors of this Association, we have gone on to our present requirement of a high school education and three years diligent study in a law school or law office. In this day of easy access, however, to the colleges and universities of this and neighboring states and the growing facilities afforded by the law school at Morgantown, is there any sound reason why we should be permanently content with any lesser standards than those fixed by the Washington Conference? 
The controversial portion of these standards is, of course, the fixed requirement of two years' preliminary training in college and the definite abandonment of the old-fashioned system of reading law in a lawyer's office as a gateway to the Bar. The oretically, we all profess a desire to see the profession elevated, and all believe that no training is too good for those who are to fill its ranks; but having in mind the pathway that we ourselves have trod, there is a certain sentimental hesitation in requiring more of our successors.

Thus, a distinguished member of this Association, in a recent minority report on the subject, has declared that these standards, retroactively applied-which may God forbid-would debar every member of the Supreme Court of West Virginia, all our federal judges, and, so far as his personal acquaintance extends, every circuit judge within the State. Who would not shrink from such wholesale slaughter! Yet the worth and distinction of our present. bench certainly does not warrant the omission of all legitimate precautions to insure that those who are to prepare the cases which they must decide, and some of whom must come to succeed them in their offices, shall be adequately trained in mind and spirit when they come to the Bar.

It is the same argumentum ad hominem which, whenever this subject is discussed, brings to the fore Patrick Henry with his scant six weeks of Coke upon Littleton and the Virginia Statutes, notwithstanding the fact that as William Wirt says, "Henry could rarely see the bearing of reported cases." Other great names in the same category are Oliver Ellsworth, whose only text books were Bacon's Abridgement and Jacobs Law Dictionary; John Marshall, with his six weeks of lectures under George Wythe; or Abraham Lincoln, digging away at his Blackstone in his country store. Obviously, these are names to conjure with, both at home and abroad. Those American lawyers who chanced to attend the meeting of the Canadian Bar at Vancouver this past summer and to listen to the debate on this identical question cannot fail to have been struck with the similarity of the problem and with the argaments adduced, even to the introduction of Lincoln as an exemplar.

But the argument proves far too much. If the system that produced such men can be relied upon to repeat and continue the performance, by all means let us leave it entirely unchanged. Measured in this balance, even our present West Virginia requirements go too far. If there is any method of determining the. identity of a Henry, an Ellsworth, a Marshall or a Lincoln in. 
embryo, let us bring him to the Bar with the least possible obstruction or delay. But until we have made certain of the as yet undiscovered natural law from which such prodigies result, let us in justice to the would-be practitioner and his prospective clients cease to depend on miracles or leave his equipment to chance.

No American will challenge the spirit that resents any closing of the door of equal opportunity. Indeed, if the practice of the law could be regarded merely as a means of livelihood, no restrictions on entrance could be justified, for the inborn right of every man to labor for his living is one that can be neither restricted nor denied. But if the law is in truth a learned profession and those who follow it are officers of the courts and ministers of justice, both those who practice and the public whom they serve are entitled to protection against ignorance, chicanery and false pretense.

It is urged that two years in college have no necessary connection with the fitness of a student to enter upon the study of the law, and that an even more valuable training can be had along other lines. The gentleman whom I have already quoted has suggested, for instance, that the student's time could be more profitably invested for two years inside the wire cages of a bank, learning the handling, the use, and one may suppose, the fugitive habits of checks, drafts, notes, and other negotiable paper. It may be frankly conceded that even colleges cannot work miracles, that many students spend their days there to small purpose, and that some are betrayed into the pursuit of rather useless learning, but if this were true of the majority of colleges, or even of the generality, the sooner their doors were closed the better for all concerned. I confess that a day by day perusal of bank checks and promissory notes does not seem to me to furnish the highest grade of intellectual exercise. They are highly interesting documents, many of them, especially to the payee, but to say the least, they lack literary variety.

How much of the law and of the lawyer's labor lies just here. How greatly his usefulness depends upon the proper use of language. Webster's declaration that "the power of clear statement is the great power at the bar" should be hung on the walls of every law school-and every lawyer's office, too, for that matter. It is true, both in and out of the courtroom; it is profoundly true upon the Bench. A nice and accurate choice of words would save many a contract from contest, many a statute from failure, and many a decision from hurtful uncertainty. Two years in col- 
lege work, if it added nothing to the equipment of a student but this, would be time well invested.

Unquestionably the thought is present in the mind of many observers in our crowded centers that two years in an American college with its personal contact, no less than its teaching, will do much for those who need a realizing sense of American ideals even more than mere scholarship. This phase of the question has been called a purely local one and to be dealt with as such. No doubt there are differences to be considered between great centers of population like New York or Chicago, where a multitude of persons, equally ignorant of our theories of government and our professional ideals, are rushing to the Bar, and localities like West Virginia, where the Bar is still fed in the main from those who, like their fathers before them, are native to the soil. The sort of material which is coming forward in the large cities is exemplified by a retort recently made by one of their number to a rebuke from a local committee on grievances. "Gentlemen," he said, "I am not at all interested in what you choose to call ethical. All I want to know is what is lawful." There is real peril here and it is no more local than a fire whose sparks may fly far across the forest. Men move to and fro in this counrty whether they are of good character or bad. Even those who are spared unpleasant contact with the unworthy must suffer by the general ill-repute they bring upon our chosen calling. It is this which justifies the action of the American Bar Association in treating admission to the American Bar as a matter of nationwide interest and demanding, so far as local differences will permit, the application of uniform rules. In this day of multiplying statutes and decisions, increasing intricacy of legal, financial, economie and social problems, and still more, of increasing effort to bring human action under regulatory control, it is no longer fair the country over, either to the student or to the public, to put immature and untrained minds to the study of the law's complexities.

Undoubtedly there are colleges and colleges, law schools and law schools, and also, one may add, lawyers' offices and lawyers' offices, and lawyers and lawyers. With this thought in mind, it was made the duty of the Council on Legal Education to prepare and publish a list of those law schools which comply with the standards set up at Cincinnati and those which do not. On this task the Council is already engaged. Its report, of course, can have no other effect than that due to information from a reliable source. From the first American law professorship founded by Thomas 
Jefferson at William and Mary in 1779, to the 147 law schools now within the continental area of the United States is a far cry, but the process of evolution has been neither equal nor uniform. Indeed, one writer on the subject, having in mind in particular the difference between part time and whole time schools, urges that there should be a corresponding division of the profession and its duties into those demanding a higher and those demanding a lesser degree of training. To a casual observer, this seems an effort to make the profession fit the law schools rather than the law schools the profession. All talk of such a division in this country is idle. Our professional habits are too deeply rooted to be changed, and after some observation of a dual profession divided into barristers and solicitors, and a unitary profession composed of ambidextrous lawyers, $I$ for one would never vote to abandon the latter system.

Another project of the American Bar Association which I desire to mention is its creation of a committee on coordination of the activities of local, state and national bar associations. A similar committee has been appointed by the Conference of Bar, Association Delegates. There are or are said to be 130,000 persons admitted to practice in the United States. It may be questioned whether so much as a majority of these are affiliated with any association whatever. Nevertheless, the only links which under our system bind the professsion together are these voluntary organizations. Necessarily they deal with similar if not identical themes and topics, each making its own program and each putting forward its own conclusions. A consolidation, or even a centralization of their activities would certainly tend to sterilize rather than enrich them, but there is much duplication of labor, especially in the field of membership. As I understand the scheme of our medical brethren, they provide that every member of a local medical society becomes ipso facto a member of his State and national organization, paying a lump sum in dues to be divided by arrangement among the three. The result has been that a profession much more individualistic and unsocial than our own has become an organized body embracing the majority of physicians and surgeons throughout the country. It is easily possible, of course, to over-organize, but there is something in the example of the Aesulapians which is worth deliberation.

I pass rapidly to another theme of a character which a mere lawyer can approach only with fear and trembling "Seek not to be a judge," says Ecclesiasticus, "lest thou be not able to take 
away iniquities; lest haply thou fear the person of a might,y man and lay a stumbling-block in the way of thine uprightness."

Notwithstanding the solemnity of this warning, it is not of record that many ambitions have been quenched by it. On the other hand, it is a matter for congratulation that so few of those who have disregarded the warning have fallen into the pitfalls that it threatens. Nevertheless, it is the purpose of the American Bar Association to put some guide posts along the road. A lawyer does not necessarily cease to be a lawyer when he becomes a judge and may still derive assistance, if he desires it, from the Standard Code of Legal Ethics. For his further aid, however, the Committee on Judicial Ethics has been created, of which Chief Justice Taft is the worthy chairman, and which is now actively engaged in the preparation of its report. Judges, like rulers, are unfortunate in that few care to remind them of their faults, and yet, being only human at the best, they cannot be infallible either in reasoning or in conduct. A particularly glaring illustration of judicial impropriety was that recently afforded by a judge who attempted to administer justice in the court room and in the baseball park at one and the same time. I have sometimes thought that every person chosen to judicial office should be required before assuming his robes to learn and recite the pithy compendium of judicial conduct contained in Lord Bacon's Essay on Judicature. How many an humble practitioner had wished for the courage to remind his august auditor that "an over-speaking judge is no well-tuned cymbal," and how sadly and how far each rare instance of judicial impropriety casts its shadow over the legal landscape.

There is but one other activity of the American Bar Association which I wish at the moment to draw to your special attention. A committee has been set up under the title of "The Committee on American Citzenship" to arouse the patriotic efforts of the bar in defense of American institutions and American ideals. Surely such an appeal cannot fall on deaf ears when addressed to a profession bound by its oath to protect and support the constitutions which embody these ideals. "The house of the lawyer," said Cicero, "is the oracle of the whole state." Let the oracle speak on this subject in no uncertain terms.

I confess that when I heard at San Francisco from the Committee on American Ideals the assertion that if the Constitution of the United States could be submitted to a vote a large number of our citizens would favor abolishing it entirely, I was both shocked 
and surprised. I found it hard to believe that such a state of things could or did exist in this country. I reflected, however, that "large" is an indefinite adjective and becomes menacing only by comparison. I cannot believe that this statement can truthfully be made of any considerable number of American citizens.

That there are many misguided souls cannot be denied. They range all the way from the ignorant or envious anarchist, ready to tear down what he either does not enjoy or cannot understand, to the sentimental reformer who, in his eagerness to reach some instant goal, is ready to overturn whatever stands in his hasty way. Of the two, one cannot be sure that the latter is not the more numerous and the more dangerous. Much of the time of the wise, as some one has sententiously remarked, must be spent in repairing the mistakes of the good. The clamor of these bears little proportion to their number, for as Jefferson says, "An individual, thinking himself injured, makes more noise than a state."

Wild theories are afloat, of course, most of them merely short cuts to power for the theorist, but the time lends itself to their spread and propagation. After every storm, the waters are troubled. The Great War and its aftermath have profoundly disturbed the foundations of society and government. Only the most purblind optimist could have hoped that its repercussions would not be felt in America as elsewhere. Men and women were taken from their normal and accustomed occupations and set to new and strange tasks. They were required to reverse the orderly habit and custom of their lives. Power was given to those who before had been impotent. Many beyond the reach of need awoke to find themselves necessitous. Labor which had once been undertaken without resentment became repugnant; moral values were ignored or greatly modified; while in the Walpurgis dance of currency inflation old standards of value disappeared or became meaningless.

It is not to be wondered at that in the name of reform one remedy after another is offered to a world whose discontent makes it eager to embrace any gospel, even when condemned by all past experience.

America, notwithstanding her comparative happiness and good fortune, has not escaped the common lot. Our communists and parlor Bolsheviki ery out against the institution of private property; they dream of a communistic state, administered, of course by themselves, although the Russian fiasco makes a sorry background for their picture of a new world. Some senators of the United States and other would-be leaders are willing, or would 
have themselves believed to be willing, to strike down our whole theory of constitutional government by transferring from the Courts to Congress the ultimate power to determine when the limit of constitutional authority has been overstepped. Perfervid reformers would use the power of amendment to write into the organic law license to crusade under the national flag against everything that falls under the bane of their displeasure; while the ultra feminist, political equality having been made secure, would now snatch the archangel's trumpet from the sky and declare by constitutional amendment that sex, like time, shall be no more.

It is not easy, however, to believe that ideas such as these do or can command the approval of a majority of Americans. I choose to believe that the heart of the country is still sound to the core, and that neither the elemental virtues nor the truths of free government have been forgotten. America, I feel sure, still retains its love of individual freedom, its belief in the inalienable right to life, liberty, and the pursuit of happiness, its respect for a constitutional system of government, giving full opportunity for majority rule, but with a strict preservation of minority rights. We are still true as a nation to the holy trinity of ideals, human equality, personal liberty, and popular sovereignty, in whose name we were baptized, and to the charter that makes these things secure.

Yesterday, today and tomorrow, however, those only are free who show themselves worthy of freedom. The ingredients change, but the laws of political action and reaction do not alter. With the increase in population, the problems of popular government become more and more difficult, and the demand for their wise solution more and more imperative. According to the census, there were in this country on the first day of January, 1921, $13,920,694$ residents who had been born abroad. Of these $6,493,088$ had become naturalized eitizens and 1,223,490 had taken out their first papers. No doubt many of this number came as strangers to our ideals of government and to our conceptions of citizenship, yet those among them who sought less rather than more freedom by the change must certainly be few. The danger with these is that they may go to the opposite extreme and, through lack of understanding, may fail to see that free government means, first of all, self-government; and that failing this, the line that marks off liberty from license may be forgotten as quoted. Yet native and new-comer alike, there is need of constant education and 
constant discipline in that most difficult of all human enterprises - the tremendously exacting task of self-government.

The weighty responsibility of the Bar is a theme too worn to be repeated here. In every democracy that ever has existed, the lawyer has been looked to as the leader of political thought. As much may fairly be said of America today. The position is a proud one. It is well for the lawyer to remember that he does not hold it without challenge.

Said the head of a labor organization recently:

"Will any one contend that the toilers of America have been properly represented in our legislative bodies? Just think it over. What excuse have the toilers of America to offer for sitting idly by and allowing the legal profession to occupy 380 out of the 531 seats in the legislative branchès of our federal government? This gives to that profession $72 \%$ of the representatives in the Congress and in the Senate of these United States, while it has been estimated that from 70 to $87 \%$ of the voters of America are engaged in occupations that cause them to be regarded as doing "manual" labor, still they have but an infinitesimal representation."

A like cry goes up day by day from the commercial world that sighs for the chmierical thing, "a business government" conducted by "business men" on "business principles." I say "ehimercial," for the cardinal aim of business is to produce a profit within the shortest time, by the most direct methods, and with the least possible discussion or debate. Such a program would make sorry havoc if applied in the political sphere. Men must labor there often with little hope of immediate result. They must be content to walk around obstacles which they cannot surmount. And they must not begrudge the endless discussion necessary to put in motion the mighty but glacial force called public opinion. It was Catherine of Russia who said to Rousseau as he expounded his theories, "That is all very well, M. Rousseau, for you philosophers who write on paper, but I poor Empress that I am, deal with a far more sensitive material; I mast write my edicts on the human skin."

Among these contenders for the prize, the lawyers will hold their leadership only if they rise to their opportunities, both as individuals and as an organized body. I confidently expect that in its efforts in this direction the American Bar Association will receive 
West Virginia Law Review, Vol. 29, Iss. 2 [1923], Art. 5

the sympathy and support of every member of the American Bar within or without its ranks. It is our task, by precept and example and by personal effort and sacrifice to preserve in this country for ourselves and our offspring-

A nation yet, the rulers and the ruled

Some sense of duty, something of a faith,

Some reverence for the laws ourselves have made,

Some patient force to change them when we will, Some civic virtue, firm against the crowd. 